\title{
RESPONSABILIDADE CIVIL POR FURTO DE VEÍCULOS OCORRIDO NO ESTACIONAMENTO DE SHOPPING CENTER
}

Cassiana de Almeida e Silva
Edwirges Elaine Rodrigues

ISSUE DOI: $10.21207 / 1983.4225 .263$

\section{RESUMO}

A responsabilidade civil é tema muito frequente no cotidiano da sociedade. É ela que reconhece a culpa dos agentes por atos ilícitos e estabelece a obrigatoriedade da indenização. Para isso, necessário se faz a análise dos requisitos da culpa, a quantificação do prejuízo suportado pela vítima, as condições para aplicação da responsabilidade, e se há concorrência de fatores diversos à vontade do agente, dentre outros. Aplicando todos esses elementos às situações experimentadas pelos consumidores que frequentam os estacionamentos de shopping centers, verificar-se-ão quais teorias e entendimentos jurisprudenciais podem ser aplicados ao caso concreto, tendo como as mais comuns a incidência de normas do Código de Defesa do Consumidor e as referentes ao contrato de depósito, disciplinado pelo Código Civil. 
Palavras-chave: Responsabilidade Civil. Código de Defesa do Consumidor. Shopping Center. Estacionamento.

\section{INTRODUÇÃO}

No presente trabalho será explanada a evolução da responsabilidade civil com seus requisitos e peculiaridades, suas modalidades, seus principais pontos e a aplicação no caso concreto.

Feito isso, seguir-se-á à apresentação de conceito e noções sobre o centro comercial que mais se desenvolve no mundo - o shopping center -, mencionando suas especificidades e, como se envolvendo numa trama, cingir-se-á todo o tema de forma a demonstrar a relação em si, especialmente no que se refere ao estacionamento ou parqueamento de veículos desses grandes centros.

Finalizando toda essa explanação, o trabalho se apoia em jurisprudências para demonstrar a dificuldade de se adequar o pouco de conceitos e entendimentos ao caso concreto.

Assim, o objeto principal desta pesquisa é tratar a responsabilidade civil sob seus diversos ângulos, com suas novas aplicações ao caso concreto, almejando levar o conhecimento aos interessados no tema. Dar oportunidade às pessoas de saberem que o mundo do Direito é mais amplo do que se pode prever. Prova disso é o presente tema: a responsabilidade civil abarca todas as atividades humanas, desde que haja uma conduta que produza dano material, moral e até mesmo estético.

\section{RESPONSABILIDADE CIVIL}

\section{$1.1 \quad$ Conceito}

É fácil encontrar o conceito de responsabilidade civil porque este é visualizado no cotidiano, dentro das relações mútuas. O conceito é deveras amplo, mas sinteticamente podemos usar como exemplo o fato de que, se alguém ultrapassa os limites das regras impostas pelas leis ou até 
mesmo pelos costumes, e causa um dano, um prejuízo a outrem, nasce para a vítima o direito de ver-se amparada, ressarcida.

Pois então, responsabilidade civil gera uma indenização que é um ressarcimento patrimonial pelo direito injustamente lesionado, cujo fundamento é o neminem laedere (não lesar ninguém). ${ }^{1}$

Quando uma pessoa faz o que não é permitido, é óbvio que comete um ato lesivo, uma vez que este ato ocorreu contra a vontade de outrem.

Para Maria Helena Diniz, a responsabilidade civil seria um conjunto de medidas que obriguem o causador do prejuízo a repará-lo, seja esse dano de forma moral ou patrimonial, ainda que causado por terceiro em razão de ato do próprio imputado, de pessoa por quem ele responde, ou de fato de coisa sob sua guarda ou, até mesmo, de simples imposição legal. ${ }^{2}$

A responsabilidade civil pode surgir pela inexecução do contrato, por ato ilícito, ou pode ser derivada de lei, sendo que em qualquer caso tem-se a indenização pelo dano causado.

\subsection{Evolução histórica}

Nos primórdios da civilização humana, os grupos de pessoas, assim que se sentissem lesadas, reagiam às ofensas e lesões sofridas de forma rápida, imediata, muitas vezes com violência. Não se falava em Direito, mas em vingança, selvageria, justiça pelas próprias mãos.

Tempos depois, essa vingança seria regulamentada por uma lei, a Lei das XII Tábuas, a pena de Talião, na qual o Estado intervém como forma de consentir ou proibir o uso arbitrário das próprias razões.

Em meio a tantos artigos da mencionada Lei, cite-se um: " $196^{\circ}$ Se alguém arranca o olho a um outro, se lhe deverá arrancar o olho". Fica evidenciado que um simples dano causado a outrem deveria ser considerado contrário ao Direito.

\footnotetext{
${ }^{1}$ ACQUATIVA, Marcus Claudio. Dicionário jurídico. São Paulo: Síntese, 1991.p. 1028.

2 DINIZ, Maria Helena. Curso de direito civil brasileiro. 19. ed. São Paulo: Saraiva, 2005. p. 40.
} 
Ressalta-se, ainda, que, para os romanos, não havia distinção entre responsabilidade civil e responsabilidade penal, sendo a mesma pena aplicada ao agente danoso.

Dentro deste contexto primitivo, observa-se o surgimento de uma forma de "composição voluntária" em que a vítima do ato danoso e o agente encontram uma forma de amenizar o prejuízo através de uma soma em dinheiro ou entrega de algum objeto.

Posteriormente, a Lei das XII Tábuas estipula uma espécie de tarifa, ou "composição legal", a ser paga pelo ofensor, como forma de pena, substituindo definitivamente a vingança privada.

Pode-se dizer que a maior evolução do instituto da responsabilidade civil, no período romano, precisamente na época de Justiniano, foi o surgimento da Lex Aquilia, que veio distinguindo responsabilidade civil delitual ou extracontratual, ou simplesmente responsabilidade civil aquiliana. Dividia-se em três capítulos, sendo o último deles o mais relevante, uma vez que foi o precursor, através da sua aplicação, pelos juristas do período, da verdadeira doutrina sobre responsabilidade civil.

Para Maria Helena Diniz,

A Lex Aquilia de damno veio cristalizar a ideia de reparação pecuniária do dano, impondo que o patrimônio do lesante suportasse os ônus da reparação, em razão do valor da res, esboçando-se a noção de culpa como fundamento da responsabilidade, de tal sorte que o agente se isentaria de qualquer responsabilidade se tivesse procedido sem culpa ${ }^{3}$.

Compartilhando da mesma opinião, Silvio de Salvo Venosa:

Foi um plebiscito aprovado provavelmente em fins do século III ou início do século II a.C., que possibilitou atribuir ao titular de bens o direito de

${ }^{3}$ DINIZ, Maria Helena. Curso de direito civil brasileiro. 19. ed. São Paulo: Saraiva, 2005. p. 11. 
obter o pagamento de uma penalidade em dinheiro de quem tivesse destruído ou deteriorado seus bens. ${ }^{4}$

Como conteúdo desse ordenamento jurídico, estavam os delitos considerados atos ilícitos, as penas a serem cominadas, o quantum de reparação pecuniária do dano causado. Por exemplo: para avaliação da indenização, observava-se o valor do objeto nos trinta dias que antecederam o fato danoso e, atendendo, de início, ao valor venal.

Com o tempo, estendeu-se o dano ao valor relativo, adequandose à jurisprudência. Nota-se, então, que a reparação poderia ser relativamente superior ao dano sofrido, caso a coisa perdesse a importância. Ousamos dizer até que nascia nesse momento uma ideia de cumulação de pedidos entre dano material, o que realmente se perdeu, e o dano moral, ainda que não com essa nomenclatura, uma vez que surgia a possibilidade de majoração na indenização a ser recebida.

O entendimento acerca da pena passou a ser, aos poucos, substituído pela imagem de reparação do dano sofrido, sendo, após, recepcionada pelo Código Napoleônico, o qual exerceu forte influência em preceitos e institutos do Código Bevilaqua, o Código Civil de 1916.

\subsection{Pressupostos da responsabilidade civil}

Como visto acima, o dano causado por meio de ato ilícito gerava uma forma de desequilíbrio jurídico-econômico entre agente causador e vítima, o que, após longo período, poderia ser amenizado com o surgimento da indenização através de prestação pecuniária ou entrega de objetos, proporcional ao dano.

A teoria da reparação do dano só passou a ser aplicada quando os juristas da época se desvencilharam da ideia de que a responsabilidade civil nascia da culpa e deram início a novos entendimentos, apontando como verdadeiro fundamento a existência de um dano efetivo.

Sem dúvida, é deveras abstruso mencionar com precisão quais os pressupostos, uma vez que doutrina e jurisprudência aplicam diversas interpretações, sem uma posição concreta. Há que se observar, ainda, que

\footnotetext{
${ }^{4}$ VENOSA, Silvio de Salvo, apud, LIMA, Alvino. Culpa e risco. 2. ed. São Paulo: Revista dos Tribunais, 1999. p.19.
} 
dentro do nosso ordenamento jurídico temos duas modalidades de responsabilidade civil, quais sejam, objetiva e subjetiva, com suas peculiaridades, que serão vistas em momento oportuno.

A análise do artigo 927, do Código Civil de 2002, permite verificar como pressupostos da responsabilidade civil a antijuridicidade, a culpabilidade, o nexo de causalidade e o dano sofrido.

A antijuridicidade se refere àquilo que é contrário ao Direito, ou seja, antijurídico. Seja uma ação ou uma omissão, por ato humano, esteja em confronto com a tranquilidade, a paz social, a segurança e a justiça, haverá um ato antijurídico.

Segundo Carlos Roberto Gonçalves, para que haja a configuração de uma responsabilidade por omissão, mister se faz a existência de um dever jurídico de efetuar aquele ato, sendo que, através de sua prática, possa ficar evidenciado que o dano seria evitado. ${ }^{5}$

A culpabilidade se divide em duas espécies, quais sejam o dolo e a culpa que, por sua vez, se dividem em três subespécies (culpa em sentido estrito): a negligência, a imprudência e a imperícia. Dolo, portanto, é a vontade, o desejo, de forma consciente, de cometer o ato ilícito, contrário ao direito. ${ }^{6}$ A culpa se apresentaria pela falta de diligência, de cuidado que um homem médio teria naquela situação.

Nota-se que, para a vítima obter a reparação do dano, há exigência de que se prove a culpa ou o dolo do agente, aplicando-se a teoria da responsabilidade subjetiva. Por existir, em muitos casos, uma dificuldade em produzir tal prova, o Código Civil, em seu artigo 936, a presume.

Para a teoria subjetiva, com relação à natureza e à extensão da culpa, pode-se distinguir entre culpa grave, leve e levíssima. Por grave, a modalidade que mais se aproxima do dolo, entende-se ser aquela imprópria ao homem médio; por leve, entende-se a falta evitável com atenção ordinária, ou seja, aquela que poderia ser evitada, uma vez que possível a atenção habitual ao caso; e, finalmente, por levíssima, entende-se como

${ }^{5}$ GONÇALVES, Carlos Roberto. Sinopses Jurídicas: responsabilidade civil. São Paulo: Saraiva, 2007. p. 17.

${ }^{6}$ GONÇALVES, Carlos Roberto. Direito civil brasileiro: responsabilidade civil, v. 4. 3. ed. São Paulo: Saraiva, 2008. p. 35. 
sendo a falta só evitável com atenção extraordinária, ou com especial habilidade ou com conhecimento singular. ${ }^{7}$

Mister se faz, ainda, classificar o elemento culpa em in eligen$d o$, que decorre de uma má escolha com relação ao seu representante; in vigilando, que decorre da falta de fiscalização; in comittendo, que é uma forma de ação, de ato positivo; in omittendo, que decorre de uma abstenção do agente; in custodiendo, que decorre da falta de cuidados na guarda de um animal, pessoa ou objeto.

O nexo de causalidade se exprime na ideia de relação entre a ação ou omissão do agente e o dano causado. Vem expresso no disposto no artigo 927, do Código Civil, através do verbo "causar". Sem ele, não se fala em obrigação de indenizar, ou seja, as excludentes de responsabilidade civil, como a culpa da vítima, o caso fortuito e a força maior, rompem o nexo, afastando a obrigação de reparar.

Por fim, deve-se analisar a existência de um dano efetivo, de ordem material (patrimonial) ou moral (extrapatrimonial), sendo este último um prejuízo que não tem repercussão na esfera financeira do ofendido. ${ }^{8}$

Ainda que preenchidos os requisitos culpa, ação ou omissão humana e nexo de causalidade, sem que haja realmente um dano, um prejuízo, não se deve cogitar a hipótese de indenização devida.

\section{$1.4 \quad$ Modalidades de responsabilidade civil}

São três as modalidades de responsabilidade civil: quanto ao fato gerador, que se subdivide em responsabilidade contratual e extracontratual; quanto ao agente, que se subdivide em direta, em que é a responsabilidade proveniente de ato do próprio agente direto do dano, e em indireta, que decorre de ato de terceiro; e por fim, quanto ao fundamento, que se subdivide em responsabilidade subjetiva e objetiva.

\subsubsection{Responsabilidade contratual e extracontratual}

7 GONÇALVES, Carlos Roberto. Direito civil brasileiro: responsabilidade civil, v. 4. 3. ed. São Paulo: Saraiva, 2008. p. 36.

8 Ibidem. 
Por responsabilidade contratual entende-se aquela decorrente de inexecução de um negócio jurídico bilateral (em que há duas ou mais partes envolvidas, estipulando direitos e obrigações recíprocas) ou unilateral (em que as regras são estabelecidas apenas por uma das partes, tendo a outra aderido sem questionamentos), ou seja, é o descumprimento de um dever contratual, sendo que a ausência de adimplemento ou da mora no cumprimento de qualquer obrigação gera um ilícito contratual e uma responsabilidade de indenização.

Carlos Roberto Gonçalves exemplifica a modalidade ao citar:

Por exemplo: quem toma um ônibus tacitamente celebra um contrato, chamado contrato de adesão, com a empresa de ônibus. Esta, implicitamente, assume a obrigação de conduzir o passageiro ao seu destino, são e salvo. Se, no trajeto, ocorre um acidente, e o passageiro fica ferido, dá-se o inadimplemento contratual, que acarreta a responsabilidade de indenizar as perdas e danos, nos termos do art. 389, do Código Civil ${ }^{9}{ }^{10}$

Em todo negócio jurídico, o acordo entre as partes estabelece um vínculo jurídico que deriva da vontade das mesmas, havendo, então, obrigações recíprocas, mútuas. Não se poderá olvidar de observar todos os requisitos essenciais para a validade de um contrato, segundo estabelece o artigo 104, do Código Civil: agente capaz, objeto lícito, possível e determinável e forma prescrita ou não defesa em lei. A inobservância de tais requisitos acarreta a nulidade do contrato, de acordo com o artigo 166, do referido diploma.

A base da responsabilidade contratual é um dever de resultado, ou seja, as partes se obrigam mutuamente almejando um objetivo comum. Em consequência disso, há uma presunção de culpa pelo não cumprimento do contrato, nascida de um ato prejudicial à outra parte. Excepcionalmente se possibilita que um dos contraentes assuma, através de cláusula expressa, o ônus de força maior ou caso fortuito.

\footnotetext{
${ }^{9}$ Art. 389: Não cumprindo a obrigação, ou deixando de cumpri-la pelo modo e no tempo devidos, responde o devedor por perdas e danos.

${ }^{10}$ GONÇALVES, Carlos Roberto. Direito civil brasileiro: responsabilidade civil, v. 4. 3. ed. São Paulo: Saraiva, 2008. p. 26.
} 
Há ainda uma possibilidade de estipulação de cláusula que reduza ou exclua o dever de indenizar, desde que não contrário à ordem pública.

Pode-se dizer que, se o contrato gera obrigações, seu inadimplemento também o gerará. É fácil perceber esse efeito dominó, uma vez que, quando ocorre a inexecução do contrato, não é a relação contratual que dá ensejo à responsabilidade, já que, através desse ato, surgiu uma nova obrigação, a de indenizar, reparar o dano em razão do inadimplemento. Para tanto, é necessário que uma primeira obrigação exista e tenha, por conseguinte, um descumprimento, por exemplo, quando um comodatário não devolve a coisa emprestada, que, por sua culpa, pereceu, ou quando um ator não comparece ao local do evento contratado. ${ }^{11}$

$\mathrm{O}$ ônus da prova incumbe ao devedor, que terá de provar, ante o descumprimento, a ausência de culpa ou a presença de uma das causas excludentes da obrigação de indenizar, tendo em vista o artigo 393, do Código Civil ${ }^{12}$, que faz referência ao caso fortuito ou força maior.

Por outro lado, tem-se a responsabilidade extracontratual ou aquiliana, a qual deriva de um ilícito extracontratual, ou seja, da realização de um ato ilícito de um certo agente, em que não haja vínculo obrigacional anterior entre os contraentes, por não estarem envolvidos por uma relação contratual.

Carlos Roberto Gonçalves aponta as diferenças entre as modalidades ao dizer que:

$\mathrm{Na}$ responsabilidade extracontratual, o agente infringe um dever legal, e na contratual, descumpre o avençado, tornando-se inadimplente. Nesta, existe uma convenção prévia entre as partes que não é cumprida. $\mathrm{Na}$ responsabilidade extracontratual,

\footnotetext{
${ }^{11}$ GONÇALVES, Carlos Roberto. Direito civil brasileiro: responsabilidade civil, v. 4. 3. ed. São Paulo: Saraiva, 2008. p. 26.

12 Artigo 393: O devedor não responde pelos prejuízos resultantes de caso fortuito ou força maior, se expressamente não se houver por eles responsabilizado.

Parágrafo único. O caso fortuito ou de força maior verifica-se no fato necessário, cujos efeitos não era possível evitar ou impedir.
} 
nenhum vínculo jurídico existe entre a vítima e o causador do dano, quando este pratica o ato ilícito. ${ }^{13}$

Essa responsabilidade deriva da inobservância de lei, acarretando uma lesão a um direito, sem que haja anteriormente uma relação jurídica entre as partes envolvidas, gerando um dever de indenizar, conforme, por exemplo, preceitua o artigo 949, do Código Civil: "No caso de lesão ou outra ofensa à saúde, o ofensor indenizará o ofendido das despesas do tratamento e dos lucros cessantes até ao fim da convalescença, além de algum outro prejuízo que o ofendido prove haver sofrido."

\subsubsection{Responsabilidade subjetiva e objetiva}

Conforme visto na evolução histórica, a responsabilidade civil era objetiva, se baseava na ideia de vingança e justiça pelas próprias mãos, não se cogitando de culpa como requisito essencial para que se pudesse reparar o dano. A reação através da violência apenas buscava aplicar uma espécie de castigo ao agente do ato lesivo.

Tendo como pressuposto a idéeia de culpa, surge a teoria clássica da responsabilidade civil, também denominada teoria da culpa ou subjetiva. Para ela, é necessária a prova de que o agente agiu com culpa, esta em sentido lato, para, posteriormente, se falar em indenização do dano experimentado. É imperioso que o ato tenha derivado de sua consciência, que tenha sido intencional, caracterizando, então, o dolo; ou ainda, que o agente tenha agido com imprudência, negligência ou imperícia.

Sem essa comprovação, a vítima deverá suportar os prejuízos como se fossem frutos de caso fortuito ou força maior.

Para Rui Stocco, doutrina e jurisprudência não vêm aplicando a responsabilidade civil fundada na culpa tradicional, não solucionando diversos conflitos e se esquecendo da reparação desses casos. ${ }^{14}$

Compartilhando desse mesmo juízo, Sérgio Cavalieri Filho argumenta:

${ }^{13}$ GONÇALVES, Carlos Roberto. Direito civil brasileiro: responsabilidade civil, v. 4. 3. ed. São Paulo: Saraiva, 2008. p. 26.

${ }^{14}$ STOCCO, Rui. A responsabilidade civil e sua interpretação jurisprudencial. São Paulo: Revista dos Tribunais, 1999. p. 52. 
Por essa concepção, todavia, a vítima só obterá a reparação do dano se provar a culpa do agente, o que nem sempre é possível na sociedade moderna. $\mathrm{O}$ desenvolvimento industrial, proporcionado pelo advento do maquinismo e outros inventos tecnológicos, bem como o crescimento populacional geraram novas situações que não podiam ser amparadas pelo conceito tradicional de culpa. ${ }^{15}$

É em meio a essa lacuna que surge a teoria da responsabilidade objetiva, ou a ainda chamada teoria do risco. Postula ela que todo dano é passível de indenização e deve ser reparado por quem a ele se liga através de um nexo causal, independentemente de culpa. ${ }^{16}$

Diferentemente do que ocorre com a responsabilidade subjetiva, a culpa, nesse caso, não é requisito para a configuração da responsabilização, sendo que, em alguns casos, esta se encontra prevista em lei, conforme se verifica nos artigos 927 a 954, do Código Civil. Assim, haverá inversão do ônus probandi, devendo o autor da ação provar, somente, a ação ou omissão e o dano por ele experimentado.

Para essa teoria, não importa a imputabilidade ou a antijuridicidade do fato danoso; só se cogita quanto à verificação da ocorrência de um evento e se dele gerou prejuízo. Assim, chega-se ao autor do dano, o responsável.

Não há que se falar em substituição de teorias, mas apenas em complementação, suprimento, uma vez que a teoria subjetiva deixava lacunas, em decorrência do progresso, que necessitavam serem preenchidas.

\subsection{Causas excludentes da responsabilidade civil}

Basicamente, a teoria da responsabilidade civil visa à indenização em decorrência de uma ação humana, geradora de um dano.

15 FILHO, Sergio Cavalieri. Programa de responsabilidade civil. 9. ed. São Paulo: Atlas, 2010. p. 16.

${ }^{16}$ GONÇALVES, Carlos Roberto. Direito civil brasileiro: responsabilidade civil, v. 4. 3. ed. São Paulo: Saraiva, 2008. p. 30. 
Entretanto, há situações que eximem o agente de sua responsabilidade, ou seja, rompem o nexo causal, desobrigando o ofensor do dever de indenizar. ${ }^{17}$ São elas, então, chamadas de excludentes de responsabilidade e algumas estão previstas no artigo 188, do Código Civil. ${ }^{18}$

Doutrinadores apontam a legítima defesa, exercício regular do direito, estado de necessidade, fato da vítima, fato de terceiro ou culpa de terceiro, caso fortuito ou força maior, cláusula de não indenizar ou cláusula de irresponsabilidade, vício da própria coisa, estrito cumprimento de dever legal, renúncia e prescrição, como sendo exemplos dessas excludentes, os quais serão objeto de estudo a seguir.

\subsubsection{Legítima defesa}

Conforme menciona Sérgio Cavalieri Filho, a legítima defesa aqui é a mesma definida no artigo 25, do Código Penal Brasileiro. O ofensor, usando de meios necessários, mas de maneira moderada, repele uma agressão injusta, atual ou iminente, a direito seu ou de outrem. E este doutrinador completa:

$\mathrm{O}$ agente se vê em face de agressão injusta, atual ou iminente, de sorte que, se não reagir, sofrerá dano injusto, quando, então, a legítima defesa faz lícito o ato, excluindo a obrigação de indenizar o ofendido pelo que vier a sofrer em virtude da repulsa à sua agressão. ${ }^{19}$

\footnotetext{
${ }^{17}$ PEREIRA, Caio Mario da Silva. Instituições de direito civil. 15. ed. Rio de Janeiro: Forense, 1997. p. 507

18 Artigo 188: Não constituem atos ilícitos:

I - os praticados em legítima defesa ou no exercício regular de um direito reconhecido;

II - a deterioração ou destruição da coisa alheia, ou a lesão a pessoa, a fim de remover perigo iminente.

Parágrafo único. No caso do inciso II, o ato será legítimo somente quando as circunstâncias o tornarem absolutamente necessário, não excedendo os limites do indispensável para a remoção do perigo.

19 FILHO, Sergio Cavalieri. Programa de responsabilidade civil. 9. ed. São Paulo: Atlas, 2010. p. 19.
} 
Analisando melhor todos os requisitos contidos no conceito de legítima defesa através das palavras de Fernando Capez, tem-se por "meios necessários" aqueles menos lesivos colocados à disposição do agente no exato momento da agressão; como, por exemplo, se o agente tem ao seu redor um canivete, capaz por si só de repelir a agressão, desnecessário se faz o uso de uma arma de fogo. O mesmo ocorre com relação à expressão "moderada", ou seja, o meio empregado deverá ser no limite do razoável para conter a agressão. Por "agressão injusta, atual ou iminente" entende-se ser aquela ação humana contrária ao direito, ao ordenamento jurídico, que está ocorrendo, já está em curso. "Iminente" é aquele ato que está prestes a ocorrer, ou seja, a lesão ainda não se iniciou, mas isso poderá ocorrer a qualquer momento. E por fim, a legítima defesa visa a proteger "direito seu, ou de outrem", o que indica a possibilidade de ocorrência de uma legítima defesa de terceiro. ${ }^{20}$

Dissecando um pouco mais o artigo 25, do Código Penal, verifica-se, ainda, que a legítima defesa se estende aos danos causados em bens materiais ou morais, de estima familiar, por exemplo.

Ressalta-se, ainda, que somente a legítima defesa real praticada contra o agressor não configura ato ilícito e, portanto, não há que se falar em ação de reparação do dano. No caso de o agente atingir terceiro por aberratio ictus, responderá pela ação e ficará obrigado a ressarcir a vítima, caso haja algum dano, sem prejuízo de uma futura ação regressiva contra o injusto ofensor.

Caracterizada a legítima defesa putativa, haverá exclusão da culpabilidade, mas não da antijuridicidade do ato, o que gera para o ofensor o dever de indenizar.

Carlos Roberto Gonçalves aponta as diferenças entre legítima defesa putativa na área cível e na criminal, ao dizer que:

Na legítima defesa putativa, o ato de quem pratica é ilícito, embora não punível por ausência de culpabilidade em grau suficiente para a condenação criminal. $\mathrm{Na}$ área cível, entretanto, a culpa, mesmo

${ }^{20}$ CAPEZ, Fernando. Curso de direito penal: parte geral. 11. ed. São Paulo: Saraiva. 2007. p. 281-287. 
levíssima, obriga a indenizar. E não deixa de haver negligência na apreciação equivocada dos fatos. ${ }^{21}$

Em suma, faz-se necessária a análise do caso concreto para aferição da extensão da legítima defesa, não se esquecendo dos casos de legítima defesa putativa.

\subsubsection{Exercício regular de direito}

Outra forma de excludente de responsabilidade, o exercício regular de direito visa à defesa da propriedade do indivíduo, através de meios moderados que assegurem a sua inviolabilidade.

Para Sergio Cavalieri Filho. "é direito exercido regularmente, normalmente, razoavelmente, de acordo com seu fim econômico, social, boa-fé e os bons costumes." 22

Nota-se, ainda, que necessário se faz ser o meio razoável, moderado, uma vez que, ultrapassado esse limite, o agente poderá causar um mal desnecessário, ocorrendo um ilícito, gerando um dever de indenizar. No caso, haverá o surgimento da figura do "abuso de direito", ato ilícito que está disposto no artigo 187, do Código Civil ${ }^{23}$, podendo citar como exemplo, dentro do nosso ordenamento jurídico, as sanções impostas ao credor que, de forma abusiva, aciona o devedor em juízo, antes do vencimento da dívida, ou mesmo quando esta foi paga.

Para Carlos Roberto Gonçalves:

$\mathrm{O}$ abuso de direito ocorre quando o agente, atuando dentro dos limites da lei, deixa de considerar a finalidade social de seu direito subjetivo e o exorbita, ao exercê-lo, causando prejuízo a outrem. Embora não haja, em geral, violação aos limites

\footnotetext{
${ }^{21}$ GONÇALVES, Carlos Roberto. Direito civil brasileiro: parte geral, v. 1. 2. ed. São Paulo: Saraiva, 2005. p. 462.

${ }^{22}$ FILHO, Sergio Cavalieri. Programa de responsabilidade civil. 9. ed. São Paulo: Atlas, 2010. p. 19.

${ }^{23}$ Artigo 187: Também comete ato ilícito o titular de um direito que, ao exercê-lo, excede manifestamente os limites impostos pelo seu fim econômico ou social, pela boa-fé ou pelos bons costumes.
} 
objetivos da lei, o agente desvia-se dos fins sociais a que esta se destina. ${ }^{24}$

\title{
1.5.3 Estado de necessidade
}

\author{
Para Sergio Cavalieri Filho,
}

$\mathrm{O}$ estado de necessidade ocorre quando alguém deteriora ou destrói coisa alheia, ou causa lesão em pessoa, a fim de remover perigo iminente. $\mathrm{O}$ ato será legítimo somente quando as circunstâncias o tornarem absolutamente necessário, não excedendo os limites do indispensável para remoção do perigo. $^{25}$

Tem-se, então, um conflito entre dois direitos contrapostos que, embora tutelados pelo ordenamento, a lei autoriza que seja solucionado pelo desaparecimento do direito menos valioso, a partir de um ponto de vista ético e humano.

Apesar de muito semelhantes, a legítima defesa e o estado de necessidade possuem algumas peculiaridades que os diferenciam: na primeira, há uma agressão dirigida à pessoa ou a seus bens; no estado de necessidade, não há uma agressão, mas uma situação de fato em que o ser detecta um bem seu em perigo de sofrer um dano. ${ }^{26}$

Em outras palavras, Sergio Cavalieri Filho afirma:

Entre a legítima defesa e o estado de necessidade há traços em comum: a lesão de um interesse alheio e o fim de afastar um dano. Porém, enquanto a legítima defesa exprime uma reação ou repulsa contra injusta agressão de outrem, o estado de necessidade tem

\footnotetext{
${ }^{24}$ GONÇALVES, Carlos Roberto. Direito civil brasileiro: parte geral, v. 1. 2. ed. São Paulo: Saraiva, 2005. p. 463.

${ }^{25}$ FILHO, Sergio Cavalieri. Programa de responsabilidade civil. 9. ed. São Paulo: Atlas, 2010. p. 19.

${ }^{26}$ PEREIRA, Caio Mario da Silva. Instituições de direito civil. 15. ed. Rio de Janeiro: Forense, 1997. p. 297.
} 
essencialmente o caráter de ação como ataque ou defesa contra um perigo não proveniente de agressão de outrem. ${ }^{27}$

Em especial, quando se tratar de hipótese de estado de necessidade, o artigo 929, do Código Civil, dispõe que necessária se faz a indenização ao dono do bem em virtude do prejuízo sofrido, caso não tenha agido o agente culposamente, assegurando a este o direito regressivo contra aquele que causou o perigo, conforme dispõe o artigo 930, do Código Civil. Trata-se de hipótese de indenização por ato lícito que tem embasamento na equidade, e não na responsabilidade.

\subsubsection{Fato da vítima}

O fato da vítima se divide em culpa exclusiva da vítima e culpa concorrente, segundo Caio Mário da Silva Pereira.

Em maior ou menor grau, a culpa da vítima atenua ou afasta totalmente a responsabilidade do agente, conforme seja concorrente ou exclusiva. Uma vez contribuída de forma exclusiva com atos que afastem a causalidade, haverá, por conseguinte, a exclusão da responsabilidade de terceiro que venha a intervir no ato danoso. ${ }^{28}$

Por culpa concorrente entende-se ser aquela que, paralelamente à ação do agente causador do fato danoso, há ainda uma ação culposa da vítima, de modo que o evento danoso decorre do comportamento culposo de ambos. ${ }^{29}$

Ainda nessa linha de pensamento, Sergio Cavalieri Filho disserta: "Havendo culpa concorrente, a doutrina e jurisprudência recomendam dividir a indenização, não necessariamente pela metade, como querem alguns, mas proporcionalmente ao grau de culpabilidade de cada um dos envolvidos." 30

\footnotetext{
${ }^{27}$ Idem. p. 19.

${ }^{28}$ DIAS, José Aguiar. Da responsabilidade civil. 10. ed. Rio de Janeiro: Forense, 1997. p. 694.

${ }^{29}$ FILHO, Sergio Cavalieri. Programa de responsabilidade civil. 9. ed. São Paulo: Atlas, 2010. p. 41.

${ }^{30}$ Idem. p. 43
} 


\subsubsection{Fato de terceiro ou culpa de terceiro}

No âmbito da teoria da responsabilidade civil, verifica-se que o agente causador do fato danoso responde pessoalmente por este, ou seja, recai sobre ele próprio o dever de indenizar. Ocorre que, por diversas vezes, o agente não responde por alguns atos que serão imputados a terceiro, pessoa estranha à relação de causalidade. ${ }^{31}$

Terceiro é alguém sem qualquer relação entre o lesado e o causador aparente do dano. $\mathrm{O}$ ato de terceiro é a causa responsável do evento, não se cogitando relação de causalidade entre a conduta do autor e o lesado. ${ }^{32}$

Assim sendo, haverá um rompimento do nexo causal e, consequentemente, a exclusão da responsabilidade. A doutrina dominante equipara o fato de terceiro ao caso fortuito ou força maior, por se tratar de uma causa diversa à conduta do agente, imprevisível e inevitável.

Alguns requisitos se fazem necessários para a configuração dessa excludente: que a conduta do terceiro atraia os efeitos do fato prejudicial e, em consequência, não responda o agente, direta ou indiretamente, pelos efeitos do dano. ${ }^{33}$

\subsubsection{Caso fortuito ou força maior}

Não há um entendimento pacificado na doutrina e na jurisprudência acerca do conceito, das semelhanças e das diferenças entre caso fortuito e força maior. Por muitas vezes, se confundem.

De modo geral e no sentido literal da expressão, caso fortuito se refere a tudo aquilo que não se pode prever (imprevisibilidade específica, relativa a um fato concreto) e que se apresenta superior às forças ou vontades humanas. Como exemplo, pode-se citar a greve, a guerra.

Ressalta-se que os modernos civilistas subdividem o caso fortuito em fortuito interno e fortuito externo. Por fortuito interno entende-se

\footnotetext{
31 GONÇALVES, Carlos Roberto. Direito civil brasileiro: parte geral, v. 1. 2. ed. São Paulo: Saraiva, 2005. p. 442.

${ }^{32}$ Idem. p. 67.

${ }^{33}$ PEREIRA, Caio Mario da Silva. Instituições de direito civil. 15. ed. Rio de Janeiro: Forense, 1997. p. 300.
} 
que o fato imprevisível e inevitável tem relação direta com a atividade desenvolvida pelo empreendedor e com os riscos a ela inerentes, por exemplo, o estouro de um pneu de um ônibus.

Em contrapartida, por fortuito externo entende-se que aquele mesmo fato imprevisível e inevitável não tem relação alguma com a atividade do empreendedor, citando-se como exemplo os fenômenos da natureza. Suas características são: autonomia em relação aos riscos da empresa e inevitabilidade. Apenas o fortuito externo exonera o empreendedor do dever de indenizar, afastando a responsabilidade civil.

Por força maior, entende-se ser o fato passível de previsão, mas que, ainda assim, não se pode evitar (inevitabilidade, tendo-se o acontecimento como inevitável em função do que seria razoável exigir), pelas mesmas razões do caso fortuito. Exemplo: acontecimentos naturais como terremoto, inundação.

São considerados excludentes, uma vez que afetam a relação de causalidade entre o dano sofrido pela vítima e a ação do agente ${ }^{34}$, ou seja, excluem o nexo causal por constituírem causa estranha à conduta do agente.

\subsubsection{Estrito cumprimento de dever legal}

Qualquer pessoa, no exercício da atividade, pública ou privada, que praticar ato no estrito cumprimento de dever legal e, em decorrência, causar dano a alguém, não estará obrigada a indenizar, salvo se sua conduta exceder os limites permitidos em lei, caso em que incorrerá na hipótese de "abuso de autoridade", previsto no artigo 187, do Código Civil.

Por vezes, o Estado, de uma certa forma, se responsabiliza pelo ato das pessoas jurídicas de Direito Público e Privado, desde que elas sejam prestadoras de serviços públicos, havendo a possibilidade de pleitear uma reparação frente a ele, conforme preceitua o artigo 37, parágrafo $6^{o}$, da Constituição Federal. ${ }^{35}$ Nesse caso, caberá ação regressiva, caso

\footnotetext{
${ }^{34}$ GONÇALVES, Carlos Roberto. Direito civil brasileiro: parte geral, v. 1. 2. ed. São Paulo: Saraiva, 2005. p. 449.

35 Artigo 37: A administração pública direta e indireta de qualquer dos Poderes da União, dos Estados, do Distrito Federal e dos Municípios obedecerá aos princípios de legalidade, impessoalidade, moralidade, publicidade e eficiência e, também, ao seguinte:
} 
o agente tenha dado causa ao dano, nas modalidades de culpa, bem como tenha agido com dolo.

\subsubsection{Renúncia e prescrição}

Por renúncia, entende-se todo ato proferido apenas por uma das partes envolvidas, sendo que esta se abdica de seu direito de crédito, ou de uma indenização, por um dano causado pela outra parte.

Seus requisitos são: a unilateralidade, já que é ato de vontade de uma das partes somente; diz-se ser abdicativa, ou seja, a parte lança mão de direito seu em face a outra parte; irrevogável, pois uma vez manifestada, não há ato capaz de desfazê-la; informal, não dependendo de forma prevista no ordenamento jurídico e, por fim, tem por objeto direito existente, através de contrato ou previsto em lei.

Doutrinadores apontam não ser a renúncia uma excludente propriamente dita da responsabilidade civil, mas presume-se direito subjetivo do titular e está consubstanciada em sua maior parte nas relações contratuais.

Por outro lado, o artigo 189, do Código Civil diz que, "violado o direito, nasce para o titular a pretensão, a qual se extingue pela prescrição, nos prazos que aludem os art. 205 e 206." Trata-se do instituto da prescrição, outra forma de excludente de responsabilidade.

Praticada uma ação e ocasionado um dano, surge uma obrigação de indenizar, uma vez estabelecido o nexo causal. Esta reparação pode tornar-se inexigível por força do instituto da prescrição, uma vez não pleiteada no prazo legal.

Nos dizeres de Sergio Cavalieri Filho:

A noção de prescrição está ligada à lesão de direito, cuja ocorrência faz surgir um novo dever jurídico para o transgressor - a responsabilidade - e novo poder jurídico para aquele que sofreu a lesão - a

$(\ldots) \S 6^{\circ}$ As pessoas jurídicas de direito público e as de direito privado prestadoras de serviços públicos responderão pelos danos que seus agentes, nessa qualidade, causarem a terceiros, assegurado o direito de regresso contra o responsável nos casos de dolo ou culpa. 
pretensão, devendo esta ser entendida como o poder de invocar a tutela do Estado. Se essa pretensão não for exercida no prazo legal, ocorre a prescrição. Em doutrina, define-se prescrição como sendo a convalescença de uma lesão de direito pela inércia do seu titular e o decurso do tempo. ${ }^{36}$

Conforme dito anteriormente, no artigo 206 do Código Civil, estão discriminados os prazos referentes à prescrição, apontando especificamente que, no caso das ações envolvendo responsabilidade civil, o prazo prescricional será de três anos contados a partir da data em que ficou constatado o fato danoso, de acordo com o parágrafo terceiro, inciso $\mathrm{V}$, do referido artigo.

Ressalta-se que os prazos previstos no Código Civil não se conflitam com outros estabelecidos no Direito Público e no Código de Defesa do Consumidor, conforme preleciona o princípio da especialidade.

Em suma, as consequências da prescrição acarretam ao titular da ação de reparação uma impossibilidade de se ver ressarcido, alcançando todos os direitos, sem distinção, além de o agente causador também ficar isento de qualquer dever.

\section{O SHOPPING CENTER}

Para entender o porquê do surgimento do shopping center, necessário se faz analisar, brevemente, a evolução do comércio e a história do shopping.

Três são as possíveis fases do comércio que se inicia na Idade Média e perdura até os dias de hoje. A primeira, o comerciante mercador, inicia-se entre o século XVIII e o século XIX; a segunda caminha desta data até o surgimento da ciência da máquina com o comerciante negociante; e por fim, a terceira, o comerciante industrial, perdura até hoje.

Os primeiros grandes centros comerciais nasceram por volta do século X a.C. e iniciaram-se com o Grande Bazaar. Localizado no atual Irã, o Grande Bazaar é uma estrutura comercial de dez quilômetros de

${ }^{36}$ FILHO, Sergio Cavalieri. Programa de responsabilidade civil. 9. ed. São Paulo: Atlas, 2010. p 132. 
estrutura coberta. Outro importante centro de compras foi o Oxford Covered Market (Mercado Coberto de Oxford), aberto oficialmente na Inglaterra em 1 de novembro de 1774, o qual existe até os dias atuais. Em 1828, os primeiros shopping centers foram criados nos Estados Unidos da América, no estado de Rhode Island. O Galleria Vittorio Emanuele II, em Milão, cujo nome homenageou o então rei da Itália, foi criado na década de $1860 .{ }^{37}$

Atualmente, a falta de tempo, o medo que assola as cidades e a diversidade de lojas e produtos ao dispor dos consumidores fizeram com que um novo centro de compra surgisse para satisfazer a vontade de uma sociedade totalmente diferente da vivida na Idade Média.

Shopping Center, segundo a ABRASCE (Associação Brasileira de Shopping Center), seria um centro comercial planejado sob uma administração única, composto de lojas destinadas à exploração comercial e à prestação de serviços, sujeitas a normas contratuais padronizadas, para manter o equilíbrio da oferta e da funcionalidade, assegurando a convivência integrada e pagando de conformidade com o faturamento. ${ }^{38}$

É um centro de alta tecnologia com os atrativos capazes de convidar a sociedade, sem distinção de classe econômica, a conhecer as comodidades desse espaço.

Por vezes, esse ente despersonalizado e despido de regramento legal próprio é assemelhado, em alguns aspectos, ao condomínio.

Qualquer natureza que a ele seja dada, o shopping center é hoje sinônimo de sucesso, comodidade, rapidez, riqueza, organização e segurança.

A atividade desempenhada por um empreendedor de shopping center ultrapassa os atos de definir linhas arquitetônicas de um edifício, demarcar áreas para lojas e comércio, contratar funcionários, determinar medidas de corredores, distribuir racional das lojas e manter a ordem e a segurança do local.

Por trás da imagem de shopping center existe uma atividade extremamente complexa que exige do empresário uma visão na escolha e seleção de unidades, no equilíbrio de competição, na decoração e no esti-

\footnotetext{
${ }^{37}$ História do Shopping Center. Disponível em: <http://www.brasilescola.com/ historia/historia-shopping-center.htm>. Acesso em: 07 de janeiro de 2010.

${ }^{38}$ MARINI, Celso. Shopping Center. Disponível em: <http://jus2.uol.com.br/doutri na/texto.asp?id=609>. Acesso em: 07 de janeiro de 2010.
} 
lo, atrativos que devem envolver a sociedade de forma convidativa. É uma relação direta entre a harmonia do local e a alta clientela que o frequentará.

Conforme já dito, o shopping center é resultado de um planejamento que visa a conciliar dentro de um centro empresarial rapidez de locomoção e conforto necessários ao corre-corre do cotidiano da sociedade atual.

São inúmeras as vantagens existentes em um shopping center, podendo ser citadas a segurança com amplo estacionamento, ponto determinante neste trabalho, o lazer, o conforto e a maior quantidade de oferta de produtos, proporcionando maior facilidade aos frequentadores. Em um curto espaço de tempo, é dada ao consumidor a oportunidade de almoçar e visitar uma variedade de lojas, sem a preocupação de sair de um local ao outro, procurando estacionamento e correndo o risco de ser assaltado em uma via pública.

O shopping center é dividido de forma a agradar a toda a sociedade, indistintamente. Observe-se que são utilizados pelo empresário diversos fatores de atração, como, por exemplo, as chamadas lojasâncoras, capazes de garantir um imenso fluxo de consumidores. No que se refere aos lojistas de porte normal, a preferência é pelos detentores de marcas mais conhecidas. E, por fim, tem-se a praça de alimentação com suas franquias variadas, e está formada a essência do pólo de consumo. ${ }^{39}$

Para completar, com relação à infraestrutura, o shopping center tem como ponto marcante o seu amplo estacionamento de veículos, ganhando vantagem substancial em relação ao comércio das vias públicas comuns.

Sintetizando o que foi dito, Fábio Ulhoa assevera:

De fato, o empreendimento denominado shopping center é mais complexo. Além da construção do prédio, propriamente dita, o empresário deve organizar os gêneros de atividade econômica que nele se instalarão. A ideia básica do negócio é pôr à disposição dos consumidores, em um local único, de cômodo acesso e seguro, a mais variada sorte de produtos e serviços. Assim, as locações devem ser

${ }^{39}$ CAMPOS, Rita Maria Silvano da Cunha. Da locação em Shopping Center. Uberaba: Uniube, 2002. p. 77. 
planejadas, atendendo às múltiplas necessidades do consumidor. Geralmente, não podem faltar em um shopping center certos tipos de serviços (correios, bancos, cinemas, lazer, etc.) ou comércios (restaurantes, lanchonetes, papelarias, etc.), mesmo que a principal atividade comercial seja estritamente definida (utilidades domésticas, moda, material de construção, etc.), pois o objetivo do empreendimento volta-se a atender muitas das necessidades do consumidor. É esta concentração variada de fornecedores que acaba por atrair maiores contingentes de consumidores, redundando em benefício para todos os negociantes. ${ }^{40}$

\section{$2.1 \quad$ Tenant mix}

Dentro de várias peculiaridades do contrato firmado entre o empreendedor e os lojistas, a mais relevante ao tema é a tenant mix, ou simplesmente mix.

$\mathrm{O}$ empreendimento shopping center nasce de um trabalho desenvolvido pelo empresário que analisa sua viabilidade, através de estudos de localização do centro empresarial, observando o potencial de consumo daquela região, de projeto arquitetônico, incluindo a locação dos espaços a lojas-âncoras e satélites e à obtenção de recursos para sua construção.

A esse conjunto de estudos dá-se o nome de tenant mix, que visa principalmente à disposição das lojas, à qualidade do ramo negocial, à capacidade e idoneidade de cada comerciante pretendente ao uso da loja, à decoração, à administração do shopping, à fiscalização e à porcentagem no lucro bruto da loja. ${ }^{41}$

Ao contrário do que ocorria antigamente, em que o comércio era instalado sempre próximo aos centros de maior densidade demográfica, os empresários de shopping center preferem locais mais afastados com terrenos de grandes dimensões, para que possam planejar, de forma

\footnotetext{
${ }^{40}$ COELHO, Fábio Ulhoa. Curso de direito comercial, v. 1. 9 ed. São Paulo: Saraiva, 2005. p. 112-113.

41 MARINI, Celso. Shopping Center. Disponível em: <http://jus2.uol.com. br/doutrina/texto.asp?id=609>. Acesso em: 07 de janeiro de 2010.
} 
mais adequada ao consumidor, aquele futuro centro de compras. Esse centro comercial receberá milhares de pessoas e necessita de um espaço que acomode a todos da melhor forma possível.

Em síntese, portanto, ao planejar um shopping, o empresário tem que ter em mente toda uma estrutura que atraia o consumidor, garantindo o máximo de conforto, segurança e a maior variedade de lojas existentes no mercado empresarial.

\section{APLICAÇÃO DA RESPONSABILIDADE CIVIL EM EVENTOS OCORRIDOS NO ESTACIONAMENTO DE SHOPPING CENTER}

O presente estudo visa a analisar os conceitos e peculiaridades da responsabilidade civil e aplicá-la em um campo específico, qual seja, o shopping center. É o que será feito a seguir. Após a explanação de ambos os temas, serão apontados os diversos entendimentos jurisprudenciais e será defendida uma tese, que não seja a mais correta, porém a que se adaptaria aos dias atuais.

Tal tema é bastante controvertido, vez que inexiste legislação específica, tampouco entendimento doutrinário majoritário capaz de apontar um norte e solucionar, em parte, os mais variados conflitos nessa área.

\subsection{Responsabilidade civil no shopping center}

Como já dito, a natureza jurídica de um shopping center por vezes é confundida com a de um condomínio especial, o que não é bem verdade. Nada obsta que, invocando o princípio da liberdade contratual, seja estipulado pelos contraentes o aparecimento de um condomínio especial, desde que presentes os requisitos da Lei $n^{\circ} 4.591 / 64,{ }^{42}$ bem como as disposições no atual Código Civil.

\footnotetext{
${ }^{42}$ Lei N ${ }^{\circ} 4.591 / 64$ - Dispõe sobre o condomínio em edificações e as incorporações imobiliárias - (DOU 21.12.64).
} 
Tratando-se de um ato ilícito ocorrido nas dependências desse centro empresarial, responde o empreendedor ou a sociedade que se organizou para explorá-lo.

É viável que seja proposta uma ação regressiva demandada pelo empresário contra os lojistas, ou associação que legalmente os represente, para reembolsar a quantia despendida com a indenização.

Para entender bem quais os locais em que a responsabilidade civil poderá ser invocada, deve-se ter em mente alguns conceitos. Por áreas comuns entendem-se os corredores, escadas rolantes, áreas de lazer e estacionamento de veículos. Nesse caso, os atos ilícitos ocorridos nesses locais e que causarem lesão estarão acobertados pelos artigos 927 e 932, inciso IV do Código Civil, sob o fundamento de que há mau funcionamento das coisas que lá estão postas, ou ainda, se o ato ilícito tem relação com um funcionário, haverá a presunção de culpa, invocando o dever de vigilância ou de escolha.

No mais, novamente frisa-se, não há regramento jurídico específico para disciplinar as relações jurídicas inerentes ao shopping center. Por sua vez, não há previsão legal do cabimento da responsabilidade civil referente ao complexo comercial, tendo em vista ser ele um empreendimento recentemente criado pela mente humana, sem disciplina no Direito brasileiro.

Portanto, caberá a análise dos conflitos ocorridos no cotidiano com suas peculiaridades, levando em conta os deveres e direitos das partes envolvidas em conjunto com o entendimento jurisprudencial majoritário, para se buscar uma solução mais acertada.

Dito isso e observada, em especial, a matéria envolvida nesse trabalho - estacionamento dos shoppings centers - pode-se dizer que a ideia de segurança oferecida por esses grandes centros serve de atrativo ao consumidor. Apesar de não se falar em distinção econômica e não ter como selecionar as pessoas que o frequentam, o shopping, ainda assim, oferece maior segurança, vez que conta com um serviço privado para garantir a ordem no local, diferentemente do que ocorre com as vias públicas.

Por todos os motivos expostos, se alguém, atraído pela segurança do local, se vê lesado ao retornar ao estacionamento e não encontra seu veículo, que foi furtado, ou sofre qualquer tipo de ofensa a direito seu, ainda nas dependências do shopping, a ele nasce o direito de se ver indenizado, com suporte no princípio da responsabilidade civil, invocando a 
Súmula 130, do Superior Tribunal de Justiça: "A empresa responde perante o cliente, pela reparação de dano ou furto de veículo ocorridos em seu estacionamento."

\subsection{Natureza jurídica dos estacionamentos de shopping center}

O shopping center é um centro mercantil extremamente organizado de forma a proporcionar aos seus consumidores o máximo de conforto e comodidade, sendo esta, talvez, a definidora do sucesso desse empreendimento comercial. O estacionamento de veículos desses centros nada mais faz do que enfatizar essa ideia de conforto, tornando-o mais eficiente.

Nas palavras de Rui Stoco, "É cediço que uma das maiores atrações que os shoppings centers e supermercados oferecem é justamente a facilidade e comodidade de estacionar. Buscam assim atrair clientes por esse meio." 43

Muito se aponta, como fator determinante para a configuração da responsabilidade desses locais, a segurança que, por ser privada, demonstra maior eficiência e menor risco de ocorrência de possíveis danos aos consumidores que lá frequentam.

Nesse sentido é o entendimento jurisprudencial:

Indenização. Responsabilidade Civil. Ato ilícito. Furto de veículo em estacionamento de shopping center. Existência de aparato de segurança a funcionar como captador de clientela. Onerosidade do serviço, ademais, embutida nos preços finais dos bens e/ou serviços operacionalizados no estabelecimento. Verba devida. Embargos recebidos. (TJSP $-4^{\text {a }}$ Câmara - Embargos Infringentes - Relator Cunha de Abreu julgamento: 27.02.92 - RJTJSP 137/388.) (g.n.)

\footnotetext{
43 STOCO, Rui. A responsabilidade civil e sua interpretação jurisprudencial. São
} Paulo: Revista dos Tribunais, 1999. p. 750. 
De outro lado, apenas esse fator não é capaz de amparar a responsabilidade de um shopping center em caso de furto ou roubo, ou de qualquer dano causado aos veículos daquele local, porque, apesar desse tipo de serviço de segurança, o espaço é um local público, de livre acesso, em que lojistas e o empresário estão também sujeitos a serem vitimados de algum delito. E mais, cabe ao Estado a segurança pública, com previsão constitucional, o que acaba por isentar o particular da responsabilidade, ainda que ofereça segurança privada.

Por outro modo, poderá o consumidor que se sentir lesado invocar a responsabilidade do estabelecimento empresarial, caso algum funcionário do local tenha concorrido com culpa.

Apesar de muito controvertida a matéria, o que se tem de verdade é que deverá ser analisado o caso concreto para a aferição ou não de responsabilidade com possível indenização, já que não se tem no ordenamento brasileiro disciplina capaz de solucionar o tema.

Tanto é verdade que, para muitos doutrinadores e juristas, a natureza jurídica dos estacionamentos de shopping center se assemelha ao contrato de depósito, ou ainda a uma prestação de serviço, prevista no Código de Defesa do Consumidor, ou ainda, a um simples dever de vigilância incumbido ao centro comercial, já que o veículo, após ser estacionado, lá permanece sob a guarda daquele local.

\subsection{Teorias divergentes sobre o tema}

Diversas são as correntes que, com fundamento ou não, vagam pela seara jurídica, à espera de uma pacificação, ou de uma simples orientação.

Os pontos mais polêmicos são a questão do comprovante impresso pelo shopping center no momento em que se ingressa no estacionamento, bem como a questão da onerosidade. Basicamente toda a falta de entendimento gira ao redor dessa problemática que, para alguns, soa como absurda e, para outros, como de extrema relevância.

Majoritariamente, entende-se que se o centro comercial oferece o local para estacionamento de carros, sem qualquer espécie de onerosidade nem emissão de comprovantes de entrada e saída de veículos - os tickets -, não há que se falar em responsabilização do shopping center 
devido à ausência de elementos que caracterizem a relação jurídica entre as partes, além do que isso tornaria a prova dificultosa.

Tal entendimento merece algumas críticas, uma vez que, apesar da falta de contraprestação direta, ou seja, do pagamento através dos tickets pelo tempo de uso daquele estacionamento, há uma forma indireta de pagamento através da compra de mercadorias, tratando-se de um negócio oneroso, de finalidade altamente lucrativa, havendo que invocar a responsabilidade civil. Esta seria uma outra corrente, fortemente discutida.

Nesse sentido segue entendimento jurisprudencial:

Indenização. Responsabilidade Civil. Ato ilícito. Furto de veículo em estacionamento de shopping. Responsabilidade da administradora. Irrelevância da ausência de depósito do veículo junto à ré, bem como da inexistência de pagamento direto, por estar devidamente incluído no preço do custo da mercadoria. Indenização devida. Recurso provido para esse fim. (TJSP $-8^{\mathrm{a}}$ Câmara - Ap. Relator Fonseca Tavares - Julgamento: 12.06.85 RJTJSP 96/156.) (g.n.)

Por outro lado, a prova se torna, de fato, muito difícil, vez que não há documento capaz por si só de comprovar o alegado pelo autor. Não se pode olvidar que, em matéria de instrução probatória, o ônus incumbirá ao autor da ação, o prejudicado pelo sinistro, havendo aplicação do disposto no artigo 333, inciso I, do Código de Processo Civil. ${ }^{44}$ Admite-se como prova tanto o ticket do estacionamento como a prova testemunhal ou confissão do condutor.

Nesse sentido, segue a jurisprudência:

\footnotetext{
44 Artigo 333: O ônus da prova incumbe:

I - ao autor, quanto ao fato constitutivo de seu direito;

II - ao réu, quanto a existência de fato impeditivo, modificativo ou extintivo do direito do autor.

Parágrafo único. É nula a convenção que distribui de maneira diversa o ônus da prova quando:

I - recair sobre direito indisponível da parte;

II - tornar excessivamente difícil a uma parte o exercício do direito.
} 
INDENIZAÇÃO - Responsabilidade Civil - Furto de veículo em estacionamento de supermercado Alegada falta de prova - Admissibilidade - Hipótese de expressa negativa dos fatos pelo réu, cabendo à demandante o ônus da prova do fato constitutivo de seu direito - Artigo 333, I, do Código de Processo Civil - Boletim de ocorrência que serve apenas como início de prova, a exigir melhor respaldo em outros elementos de informação - Ação improcedente Recurso não provido. O Boletim de Ocorrência não é suficiente como prova do furto, pois representa simples registro de queixa do particular à autoridade policial. (TJSP - Apelação Cível no 188.529-1Relator: Euclides de Oliveira - Julgamento 11.05.93) (g.n.)

Como se vê neste outro julgado, o ônus da prova se regula pelo Código de Processo Civil e não pelo Código de Defesa do Consumidor.

RESPONSABILIDADE CIVIL - Alegação de furto em estacionamento de supermercado - prova inconvincente quanto ao furto naquele local - ônus que cabia ao autor da ação - artigo 333 - I do Código de Processo Civil. Recurso provido para julgar improcedente a ação de indenização. Incumbindo ao autor a prova acerca do fato constitutivo do seu direito, a ele cabe demonstrar que seu veículo fora furtado no estacionamento de supermercado, para deste exigir a respectiva indenização. (TJPA $-4^{a}$ Câmara Cível - Apelação nº 51294 - Relator Troiano Neto.) (g.n.)

Com relação a não emissão de tickets por parte do centro comercial, não há que se falar em descaracterização do dever de vigilância imposto ao shopping center.

Nesse sentido segue o julgado:

Há responsabilidade civil do shopping center por furto de veículo ocorrido em seu estacionamento, pois, destinando área para tal finalidade com intuito 
de atrair a clientela, o estabelecimento assume o dever de vigilância, pouco importando que, no sentido direto, não haja contraprestação pecuniária pelo respectivo uso ou que não seja utilizado o sistema de entrega de comprovantes de estacionamento. (TJSP - $5^{\text {a }}$ Câmara - Apelação Relator Marcio Bonilha - Julgamento 22.03.90 - RT 655/78.) (g.n.)

Outra corrente sustenta que, se há emissão de tickets, haverá a relação jurídica entre shopping center e consumidor, o que caracteriza o dever de vigilância e a possível indenização por prejuízos sofridos. Sendo oneroso o estacionamento, sempre haverá responsabilidade, uma vez que o dever de guarda do bem significa uma contraprestação devida pelo pagamento recebido.

De outro lado, há quem diga que, caso não haja cobrança pelo estacionamento, o shopping forneceria uma cortesia ou liberalidade, mas longe de inexistir o dever de vigilância.

Tal entendimento é combatido pela jurisprudência, que entende:

O shopping center é civilmente responsável pelo furto de veículo ocorrido em estacionamento colocado à disposição da clientela. Nem se argumente que o serviço do estacionamento é gratuito pela falta de contraprestação pecuniária, uma vez que o preço está incluído no valor das mercadorias ou dos serviços prestados. (TJSP $-4^{\text {a }}$ Câmara - Apelação - Relator Cunha de Abreu Julgamento 25.07.91 - RT 677/117.) (g.n.)

A outra parte da doutrina entende por bem aplicar ao estacionamento de shopping center a natureza de contrato de depósito, ou característica de mera prestação de serviço ou, por fim, um dever de vigilância, que serão estudados a seguir.

\subsection{Contrato de depósito}

Carlos Roberto Gonçalves define como: 
Depósito é o contrato em que uma das partes, nomeada depositário, recebe da outra, denominada depositante, uma coisa móvel, para guardá-la, com a obrigação de restituí-la na ocasião ajustada ou quando lhe for reclamada (Depositum est, quod custodiendum alicui datum est). ${ }^{45}$

Para Maria Helena Diniz, o conceito de depósito seria "o contrato pelo qual um dos contraentes (depositário) recebe do outro (depositante) um bem móvel, obrigando-se a guardá-lo, temporária e gratuitamente, pra restituí-lo quando for exigido". ${ }^{46}$

Para Washington de Barros Monteiro, o contrato de depósito pela própria natureza é uma estipulação intuitu personae, porque fundada nas qualidades pessoais do depositário, como a honradez e a estrita probidade. $^{47}$

Essa modalidade contratual está prevista nos artigos 627 a 652 , do Código Civil de 2002, e possui características que merecem ser ressaltadas, tais como: primeiramente, sua finalidade é a guarda de coisa alheia; o segundo traço marcante para a existência de tal contrato é a entrega da coisa, ou tradição; a terceira característica se refere à natureza do objeto, que deverá ser móvel; a quarta diz respeito à sua temporariedade, ou seja, o bem será guardado até que o depositante o reclame; e por fim, a quinta característica faz referência à gratuidade, salvo convenção em contrário, se resultante de atividade negocial ou se o depositário o praticar por profissão.

Pois bem, para muitos juristas essas características não estão presentes na relação jurídica entre o consumidor e o empreendimento shopping center devido à questão da tradição e da exigência de formalismo para a efetivação de um contrato de depósito, que estaria demonstrado através dos tickets que controlam a entrada e saída dos veículos, sendo que muitas vezes não é possível a sua emissão.

Nesse sentido é o entendimento jurisprudencial:

\footnotetext{
${ }^{45}$ CONÇALVES, Carlos Roberto. Direito civil brasileiro: responsabilidade civil, v. 4. 3. ed. São Paulo: Saraiva, 2008. p. 360.

46 DINIZ, Maria Helena. Curso de direito civil brasileiro. 19. ed. São Paulo: Saraiva, 2005. p. 330.

${ }^{47}$ MONTEIRO, Washington de Barros. Direito civil. São Paulo: Saraiva, 1995. p. 84.
} 
I- Comprovada a existência de depósito, ainda que não exigido por escrito, o depositário é responsável por eventuais danos à coisa. II- Depositado o bem imóvel (veículo) (sic), ainda que gratuito o estacionamento, se este se danifica ou é furtado, responde o depositário pelos prejuízos causados ao depositante, por ter aquele agido com culpa in vigilando, eis que é obrigado a ter na guarda e conservação da coisa depositada o cuidado e diligência que costuma ter com o que lhe pertence (art. 1.266, primeira parte, do Código Civil [atual artigo 629]). (STJ $-3^{\text {a }}$ Turma - Recurso Especial Relator Waldemar Zveiter - julgamento 16.10.90 RSTJ 29/324). (g.n.)

Com relação à questão da tradição, fica evidenciado que, apesar da existência de um funcionário que orienta os motoristas nesses estacionamentos, não há que se falar em entrega do bem, porque não se trata de um "guardador de carros", conforme descreve Caio Mário da Silva Pereira. $^{48}$

Além disso, muitos doutrinadores afirmam que a chave fica na posse do proprietário do carro, não se falando em entrega efetiva aos funcionários que gerenciam os estacionamentos. Outros desmerecem essa modalidade de contrato em virtude da presença de onerosidade, uma vez que diversos estabelecimentos comerciais passaram a cobrar pelo parqueamento de veículos, afastando a gratuidade exigida no depósito.

Rui Stoco entende de forma diversa ao dizer que, "nem vem a pelo o argumento de que essa permissão de estacionar é gratuita, de mera cortesia e que o contrato de depósito é oneroso." ${ }^{49}$ E completa:

Discordamos frontalmente desse entendimento. No que pertine à questão fática e ao id quo plerunque accidit, não há como aceitar a afirmação de que o usuário de estacionamento de shopping center ou do supermercado não estabelece um contrato tácito de

\footnotetext{
${ }^{48}$ PEREIRA, Caio Mario da Silva. Instituições de direito civil. 15. ed. Rio de Janeiro: Forense, 1997. p. 237.

${ }^{49}$ STOCO, Rui. A responsabilidade civil e sua interpretação jurisprudencial. São

Paulo: Revista dos Tribunais, 1999. p. 750.
} 
depósito do veículo, ou que não tenha transferido sua guarda ao estabelecimento. Para nós, o fato de o usuário poder escolher o local e a vaga do estacionamento que mais lhe convém e ainda, ficar de posse das chaves do veículo, não descaracteriza a transferência da guarda. ${ }^{50}$

Ainda acerca desse entendimento de ser o estacionamento de shopping um local de depósito, Rui Stoco menciona que os vigilantes não são meros orientadores de direção para estacionar, mas estão lá para evitar a ocorrência de furtos, roubos e outros danos. E por fim, diz que o contrato não exige instrumento escrito, tampouco formalismos, apontando que a inexistência de comprovante de entrega do bem não descaracteriza o contrato em si. ${ }^{51}$

Diante de tanta controvérsia, fica difícil dizer quem está com a razão, cabendo analisar todos os apontamentos e aplicar o que mais lhe aprouver ao caso concreto.

\subsection{Da prestação de serviço - relação de consumo}

A controvérsia acerca da natureza jurídica dos estacionamentos se estende de tal forma que, para muitos doutrinadores, essa relação se caracterizaria como uma relação de consumo.

Para Sílvio de Salvo Venosa, a prestação de serviço pode ser conceituada como "o contrato sinalagmático pelo qual uma das partes, denominada prestador de serviço, obriga-se a prestar serviços à outra, denominada dono do serviço, mediante remuneração." ${ }^{52}$ Tal conceito se refere às disposições do Código Civil.

O que ocorre é que este capítulo da responsabilidade civil não é regido mais pelas normas do Código Civil, vez que este possui caráter residual após o advento da Consolidação das Leis Trabalhistas e do Código de Defesa do Consumidor.

50 STOCO, Rui. A responsabilidade civil e sua interpretação jurisprudencial. São Paulo: Revista dos Tribunais, 1999. p. 750.

${ }^{51}$ Ibidem.

52 VENOSA, Silvio de Salvo. Direito civil: contratos em espécie. 3. ed. São Paulo: Atlas, 2003. p. 187. v. 3 
Em se tratando de Código de Defesa do Consumidor, tem-se duas classes: os consumidores e os fornecedores. Por fornecedor, entende-se toda pessoa física ou jurídica, privada ou pública, nacional ou estrangeira, bem como os entes despersonalizados, que desenvolvem atividade de produção, montagem, criação, construção, transformação, importação, exportação, distribuição ou comercialização de produtos ou prestação de serviços, conforme dispõe o artigo $3^{\circ}$, do referido diploma.

Portanto, o empreendedor do shopping center é um fornecedor, uma vez que presta serviços aos consumidores, bem como comercializa produtos.

Tomando como base esse entendimento, algumas considerações devem ser feitas. A partir do momento em que se opta por aplicar as disposições referentes às relações de consumo, muda-se a regra e novos pontos surgem, como é o caso da responsabilidade civil que, para o Código de Defesa do Consumidor, é obrigatoriamente objetiva, ou seja, independe de culpa e o ônus da prova se inverte, cabendo ao pólo passivo da ação provar que tal fato não ocorreu.

Nos dizeres de Rui Stoco:

E, como legítimo prestador de serviço oneroso de estacionamento, atrás de contrato firmado com o cliente - pois o valor é cobrado pela administração do shopping center independentemente de $\mathrm{o}$ proprietário do veículo consumir ou adquirir produtos em qualquer dos estabelecimentos - , tal avença insere-se na previsão do Código do Consumidor, de modo que a responsabilidade é objetiva, só elidida se demonstrada uma das causas excludentes, como o caso fortuito, a força maior ou a culpa exclusiva da vítima. ${ }^{53}$

Em complemento ao elucidado acima, cumpre ressaltar que, em caso de furto ou roubo de veículo estacionado e sob a guarda do shopping center, não há que se falar em força maior, nem com ela se identifica.

${ }^{53}$ STOCO, Rui. A responsabilidade civil e sua interpretação jurisprudencial. São Paulo: Revista dos Tribunais, 1999. p. 750. p. 751 
No início desse trabalho foi demonstrada toda a evolução da responsabilidade civil e o surgimento do conceito de culpa. Pois bem, tal conhecimento será aplicado agora.

Em seu artigo 14, o Código de Defesa do Consumidor, atento aos novos rumos da responsabilidade civil, consagrou a responsabilidade objetiva do fornecedor, se atendo basicamente ao fato de que vivemos hoje em uma sociedade eminentemente de produção e consumo em massa, responsável pela miscigenação entre os pólos de consumo e produção. 54

Para quem defende essa tese de relação de consumo, haveria, então, com o furto do veículo estacionado no parqueamento do shopping, um rompimento no serviço prestado, gerando um dever de indenizar, prescindindo de culpa, invocando o Código de Defesa do Consumidor, bem como a Súmula 130 do Superior Tribunal de Justiça.

Com este entendimento, segue a jurisprudência:

DIREITO CIVIL. RESPONSABILIDADE CIVIL. FURTO EM ESTACIONAMENTO. SHOPPING CENTER. VEÍCULO PERTENCENTE A POSSÍVEL LOCADOR DE UNIDADE COMERCIAL. EXISTÊNCIA DE VIGILÂNCIA NO LOCAL. OBRIGAÇÃO DE GUARDA. INDENIZAÇÃO DEVIDA. PRECEDENTES. RECURSO PROVIDO. I - Nos termos do enunciado n. 130/STJ, "a empresa responde, perante o cliente, pela reparação de dano ou furto de veículo ocorridos em seu estacionamento". II - A jurisprudência deste Tribunal não faz distinção entre o consumidor que efetua compra e aquele que apenas vai ao local sem nada dispender. Em ambos os casos, entende-se pelo cabimento da indenização em decorrência do furto de veículo. III - $A$ responsabilidade pela indenização não decorre de contrato de depósito, mas da obrigação de zelar pela guarda e segurança dos veículos estacionados no local, presumivelmente seguro. (STJ - Ac. Unân.

${ }^{54}$ GONÇALVES, Carlos Roberto. Direito civil brasileiro: parte geral. 2. ed. São Paulo: Saraiva, 2005. p. 260. 
da Côrte Especial de 06.02.2003 - RESP 437649 Rel. Ministro Sálvio de Figueiredo Teixeira.) (g.n.)

Como não há no ordenamento brasileiro limitação a indenização ou indenização tarifada, o fornecedor, diante de um dano causado ao consumidor, deverá indenizá-lo na sua integralidade, não podendo essa indenização ser excluída por meio de cláusula contratual que impossibilite, atenue ou exonere essa responsabilidade. ${ }^{55}$

Exemplificando o citado, tem-se as placas frequentemente encontradas nas paredes dos estacionamentos com os dizeres de não responsabilização pelos eventuais danos ocasionados no local. Com o advento do Código de Defesa do Consumidor, tal prática restou sem eficácia, ante a proibição da cláusula de não indenizar.

A título de curiosidade, menciona-se uma prática inovadora que auxilia os empreendedores do shopping center na hora do pagamento da indenização por ato ilícito. O crescente número de casos de furto a estacionamento em São Paulo levou à aprovação da Lei Municipal no 10.297, de 08 de janeiro de 1991, através do Decreto 30.102, de 04 de setembro de 1991, que tornou obrigatória a contratação de seguro por parte de shoppings centers, contra furto ou roubo de veículos, por lojas de departamento, supermercados e empresas que operam ou disponham de área ou local destinado a estacionamentos abertos ao público em geral, cujo número de vagas seja superior a 50 veículos (vide Anexo II).

Nesse sentido é o entendimento jurisprudencial:

Indenização. Responsabilidade civil. Ato ilícito. Furto de veículo em estacionamento de shopping center. Existência de vigilância ostensiva no local, além de contrato de seguro, mantido pelo réu, por danos causados a terceiros. Gratuidade do serviço e permanência do veículo na posse de seu motorista, que não excluem o dever de indenizar. Ação procedente. Recurso não provido. (TJSP $-1^{\mathrm{a}}$ Câmara - Apelação - Relator Luís de Macedo - Julgamento: 22.08.89 - RJTJSP 123/154.) (g.n.)

55 JÚNIOR, Nelson Nery. Aspectos da responsabilidade civil do fornecedor no Código de Defesa do Consumidor. São Paulo: Revista dos Tribunais, 1999. p. 78. 
Para os seguidores dessa vertente, havendo a quebra do serviço pelo empreendimento e ocorrido um dano, nasce o direito de invocar a proteção do diploma consumerista, com respaldo na responsabilidade civil objetiva.

\subsection{Do dever de guarda}

Para uma parte da doutrina, ainda que minoritária, a natureza jurídica do estacionamento de shopping center seria semelhante ao mero dever de guarda.

Para esses seguidores, não há que se falar em depósito tácito, nem em efetiva entrega do veículo por parte do proprietário à outra parte, mas sim em um vínculo do qual surge para o shopping center um dever de vigilância.

Carlos Roberto Gonçalves, um dos que entendem ser plausível essa teoria, explica que o estacionamento pode ser gratuito ou não, com entrega ou não de chaves ao guarda do local, tendo o aparato de segurança; porém, o que justifica o dever de vigilância é a finalidade à qual esse parqueamento se destina, ou seja, finalidade de inspirar segurança a quem vai até o local. ${ }^{56}$

E completa sustentando que, quando no estacionamento não existe esse aparato de segurança, e se trata de simples parqueamento cedido gratuitamente aos fregueses, não se pode assumir que haja dever de vigilância dos veículos. Nesse caso, inexistiria qualquer fato que apontasse a responsabilidade civil do shopping center.

Muito se fala que esse dever de guarda é requisito de validade apenas do contrato de depósito, bem por isso que uma corrente admite a modalidade como um tipo de natureza jurídica do estacionamento. Pois bem, conforme dito acima, o dever existirá sempre que houver segurança privada no local e que isso estimule o consumidor a frequentá-lo.

A fim de confirmar este entendimento, segue o julgado:

Sempre que, no âmbito doutra relação jurídica, como a que se estabelece entre os fregueses e os centros

${ }^{56}$ GONÇALVES, Carlos Roberto. Direito civil brasileiro: parte geral. 2. ed. São Paulo: Saraiva, 2005. p. 286. 
comerciais (shopping center), supermercados, etc, o vendedor ou o prestador de serviço ofereça por obrigação legal ou simples conveniência econômica, espaço próprio para veículos, assume dever de custódia. De modo que, se não presta a vigilância devida, responde pelos danos consequentes. (TJSP $2^{\mathrm{a}}$ Câmara - Embargos Infringentes - Relator Cezar Peluso - Julgamento 30.06.92 - RT 696/97).

Desnecessária é a aplicação dessa tese, uma vez que essa busca incessante por encontrar uma classificação contratual típica para a natureza do estacionamento não afasta a responsabilidade, visto que haveria uma culpa extracontratual por falta de diligência, de prevenção e de negligência.

Incabível a ideia de que uma pessoa suportará os danos e prejuízos de um ato ilícito, em razão da não tipicidade contratual ou devido à ausência de codificação para o caso.

\section{CONSIDERAÇÕES FINAIS}

O Direito nasceu para regular o comportamento, tanto normal quanto anormal, para dizer o que é certo e errado, o que se pode ou não fazer, o que é moral e amoral; nasceu para amenizar os conflitos experimentados no cotidiano.

No que tange à aplicação da teoria da responsabilidade civil, o legislador do Código Civil de 2002 fez exatamente isso: analisou os casos mais frequentes e lhes apontou soluções, normatizando-os.

Ocorre que a sociedade evolui de forma mais rápida que as leis. A capacidade da mente humana é tamanha que novos casos, polêmicos ou não, absurdos ou não, surgem de maneira avassaladora, que é inversamente proporcional à produção de leis.

Especialmente no caso do estacionamento de shopping center, observa-se uma infinidade de correntes que tentam solucionar os conflitos nele surgidos de maneira eficiente, tendo em vista uma deficiência no ordenamento jurídico. Conforme apresentado de forma introdutória, temse a problemática com relação à emissão de comprovantes de entrada e saída de veículos do estacionamento desse centro comercial, uma vez que 
uma vertente opta pela sua imprescindibilidade, tanto como elemento de prova - suscitando o dever de vigilância - quanto de pagamento direto, enquanto outra entende que, mesmo ausente sua emissão, existiria uma contraprestação indireta de pagamento através da compra de mercadorias do shopping.

Há o entendimento de ser o parqueamento do shopping center um contrato de depósito, o que é combatido por questões referentes à tradição, ao formalismo exigido para a efetivação do referido contrato, à onerosidade (incompatível com a gratuidade dessa modalidade contratual) e à posse. Rui Stoco entende ser possível a aplicação dessa corrente, combatendo todas essas questões apontadas.

Há quem diga se tratar de uma prestação de serviços ou relação de consumo, disciplinada pelo Código de Defesa do Consumidor, apresentando a figura do empreendedor do shopping center como se tratando de fornecedor e tendo como característica ser um prestador de serviços e comercializador de produtos. Para os seguidores dessa vertente, com a ocorrência de um ato ilícito haveria o rompimento no serviço disponibilizado, gerando um dever de indenizar, prescindindo de culpa.

Em que pese esse entendimento, deve-se ressaltar que mudanças ocorrem com relação à responsabilidade civil - que passa a ser objetiva -, bem como haverá inversão do ônus da prova, cabendo ao pólo passivo da ação provar que o sinistro não ocorreu, por exemplo.

Por fim, há entendimento apontando que a natureza jurídica do estacionamento de shopping center é semelhante ao dever de guarda. Carlos Roberto Gonçalves defende tal vertente, justificando tratar-se de um dever de vigilância devido à sua finalidade, qual seja, inspirar confiança através da segurança daquele local.

Em síntese, o que se observa é a existência de uma responsabilidade em virtude do enunciado 130 do Superior Tribunal de Justiça. Cabe, então, ante a ausência de uma legislação específica, analisar o caso concreto e adaptá-lo a uma das correntes apresentadas, a fim de que se possa amenizar o prejuízo sofrido pela vítima.

\section{REFERÊNCIAS}

ACQUATIVA, Marcus Claudio. Dicionário jurídico. São Paulo: Síntese, 1991. 
BASILIO, João Augusto. Shopping center. São Paulo: Renovar, 2005.

CAHALI, Yussef Said. Dano e indenização. São Paulo: Revista dos Tribunais, 1980.

CAMPOS, Rita Maria Silvano da Cunha. Da locação em Shopping Center. Uberaba: Uniube, 2002.

CAPEZ, Fernando. Curso de direito penal: parte geral. 11. ed. São Paulo: Saraiva. 2007.

COELHO, Fábio Ulhoa. Curso de direito comercial. 9 ed. São Paulo: Saraiva, 2005. v. 1

DENARI, Zelmo. Responsabilidade civil do fornecedor. Revista do Advogado, n. 33.

DIAS, José Aguiar. Da responsabilidade civil. 10. ed. Rio de Janeiro: Forense, 1997.

DINIZ, Maria Helena. Curso de direito civil brasileiro. 19. ed. São Paulo: Saraiva, 2005.

FILHO, Mario Cerveira. Shopping Centers: direito dos lojistas. 3. ed. São Paulo: Saraiva, 2008.

FILHO, Rodolfo Pamplona. Novo curso de direito civil: responsabilidade civil. 8. ed. São Paulo: Saraiva, 2010. v. 3.

FILHO, Sergio Cavalieri. Programa de responsabilidade civil. 7. ed. São Paulo: Atlas, 2007.

GONÇAVES, Carlos Roberto. Direito civil brasileiro: parte geral. 2. ed . São Paulo: Saraiva, 2005. v. 1.

. Sinopses jurídicas: responsabilidade civil. São Paulo: Saraiva, 2007.

Direito civil brasileiro: responsabilidade civil. 3. ed. São Paulo: Saraiva, 2008. v. 4.

Direito civil brasileiro: contratos e atos unilaterais. 5. ed. São Paulo: Saraiva, 2008. v. 3.

GONZALEZ, Cristiane Paulsen. Código de Defesa do Consumidor na relação entre lojistas e empreendedores. São Paulo: Livraria do Advogado, 2008.

História do Shopping Center. Disponível em: $<$ http://www.brasilescola.com/historia/historia-shoppingcenter.htm>. Acesso em: 07 de janeiro de 2010.

JÚNIOR, Nelson Nery. Aspectos da responsabilidade civil do fornecedor no Código de Defesa do Consumidor. São Paulo: Revista dos Tribunais, 1999. 
KARPAT, Ladislau. Shopping Center: aspectos legais e novos rumos. São Paulo: Saraiva, 1999.

LIMA, Alvino. Culpa e risco. 2. ed. São Paulo: Revista dos Tribunais, 1999.

MAMEDE, Gladston. Contrato de locação em Shopping Center. São Paulo: Del Rey.

MARINI, Celso. Shopping Center. Disponível em: <http://jus2.uol.com.br/doutrina/texto.asp?id=609>. Acesso em: 07 de janeiro de 2010.

MONTEIRO, Washington de Barros. Direito civil. São Paulo: Saraiva, 1995.

PEREIRA, Caio Mario da Silva. Instituições de direito civil. 15. ed. Rio de Janeiro: Forense, 1997.

SANSEVERINO, Paulo de Tarso Vieira. Responsabilidade civil e o código do consumidor e a defesa do fornecedor. 3. ed. São Paulo: Saraiva, 2010.

STOCCO, Rui. A responsabilidade civil e sua interpretação jurisprudencial. São Paulo: Revista dos Tribunais, 1999.

- Tratado de responsabilidade civil. São Paulo. Revista dos Tribunais: 2007.

RODRIGUES, Silvio. Direito civil: responsabilidade civil. 30. ed. São Paulo: Saraiva, 2007. v. 4.

VENOSA, Silvio de Salvo. Direito civil: contratos em espécie. 3. ed. São Paulo: Atlas, 2003. v. 3.

Direito civil: responsabilidade civil. 10. ed. São Paulo: Saraiva, 2010. v. 4. 
